\title{
Relapse in the External Auditory Canal of Acute Promyelocytic Leukemia after Treatment with All-Trans Retinoic Acid
}

\author{
Tadasu Tobita, Kaori Shinjyo, Mitsuaki Yanagi, Akihiro Takeshita, Kazunori Ohnishi and Ryuzo Ohno
}

\begin{abstract}
A 54-year-old female was admitted to our hospital for gingival bleeding and was diagnosed as acute promyelocytic leukemia (APL). She received induction therapy according to the AML92 protocol of the Japan Adult Leukemia Study Group (JALSG) with all-trans retinoic acid (ATRA) plus chemotherapeutic agents. She achieved complete remission, but one year later had a relapse in her external auditory canal without leukemic cell in the bone marrow. Extramedullary disease is rare in APL. This case suggests the importance of careful observation for extramedullary relapse in patients who are treated with ATRA. (Internal Medicine 36: 484-486, 1997)
\end{abstract}

Key words: extramedullary disease, leukemia cutis

\section{Introduction}

Differentiation therapy with all-trans retinoic acid (ATRA) has now become first line therapy for acute promyelocytic leukemia (APL), and results in greater than $80 \%$ complete remission without serious complications. ATRA differs from conventional agents by inducing differentiation of the immature malignant cells. However, there may be some unknown problems.

Extramedullary relapse is rare in APL, when treated with conventional chemotherapy. We report here a patient with APL who obtained complete remission with ATRA, but had a relapse in the external auditory canal during complete hematological remission. This is the first case of an isolated initial site of relapse in the external auditory canal, which was molecularly confirmed as PML/RAR $\alpha$.

\section{Case Report}

A 54-year-old woman was referred to our hospital on May 18, 1994 due to prolonged gingival bleeding after tooth extraction. Her white cell count was $46.0 \times 10^{9} / l$ with $72 \%$ abnormal promyelocytes in the peripheral blood, and bone marrow was characteristic for APL with 71\% abnormal promyelocytes and $1 \%$ blasts. Chromosomal analysis revealed 19 of 20 metaphases to be $46 \mathrm{XX} ; \mathrm{t}(15 ; 17)$ and 1 to be $46 ; \mathrm{XX}$. PML/RAR $\alpha$ mRNA was positive by the RT-PCR method.

She received an induction therapy according to the AML92 protocol of the Japan Adult Leukemia Study Group (JALSG) with ATRA $45 \mathrm{mg} / \mathrm{m}^{2}$ orally daily plus behenoyl cytarabine (BHAC) $200 \mathrm{mg} / \mathrm{m}^{2}$ for 5 days and daunorubicin (DNR) $40 \mathrm{mg} /$ $\mathrm{m}^{2}$ for 3 days intravenously (1). She achieved complete remission on day 43 and ATRA was discontinued on day 47. From July 1,1994 , she received the first consolidation therapy with mitoxantrone $7 \mathrm{mg} / \mathrm{m}^{2}$ daily for 3 days and continuous cytarabine (Ara-C) $200 \mathrm{mg} / \mathrm{m}^{2}$ for 5 days intravenously. From August 11 , she received the second consolidation with BHAC $200 \mathrm{mg} / \mathrm{m}^{2}$ for 5 days, etoposide $100 \mathrm{mg} / \mathrm{m}^{2}$ for 5 days and DNR $40 \mathrm{mg} / \mathrm{m}^{2}$ for 3 days intravenously and 6-mercaptopurine (6-MP) $70 \mathrm{mg} /$ $\mathrm{m}^{2}$ for 7 days orally. From Sept. 20, 1994, she received the third consolidation with BHAC $200 \mathrm{mg} / \mathrm{m}^{2}$ and aclarubicin (ACR) $14 \mathrm{mg} / \mathrm{m}^{2}$ intravenously daily for 7 days. She received G-CSF for severe granulocytopenia after each consolidation therapy. Then, she received three courses of maintenance/intensification therapy according to the AML92 protocol every 2 months. In June 1995, she noticed difficulty of hearing in her left ear, and otological inspection showed a tumor in the left external auditory canal (Fig. 1). Biopsy showed mature and immature granulocyte infiltration which was highly suspective but inconclusive for relapse (Fig. 2). Bone marrow evaluation at that time was normal with $2 \%$ normal promyelocytes and no blasts. She received the fourth course of maintenance therapy with BHAC

From the Department of Medicine III, Hamamatsu University School of Medicine, Hamamatsu 


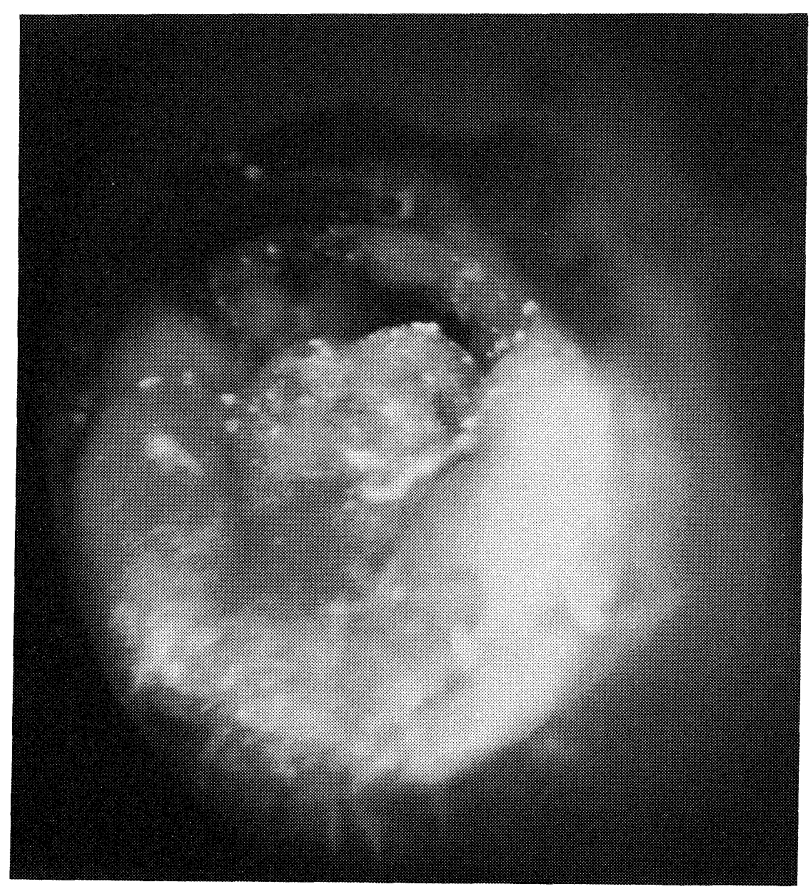

Figure 1. Tumor in the left external auditory canal. Red colored tumor occupies the external auditory canal.

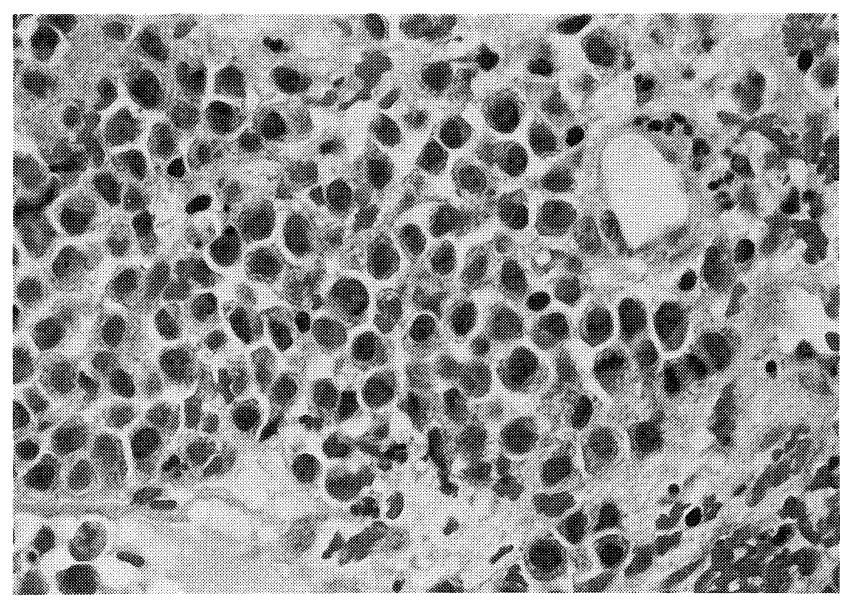

Figure 2. Histology of the biopsied tumor (HE stain, $\times 400$ ). Biopsy showed mature and immature granulocyte infiltration.

$170 \mathrm{mg} / \mathrm{m}^{2}$ for 5 days, ACR $14 \mathrm{mg} / \mathrm{m}^{2}$ for 4 days intravenously, and $6-\mathrm{MP} 70 \mathrm{mg} / \mathrm{m}^{2}$ for 7 days orally, and the tumor disappeared. When she was admitted for the fifth maintenance/ intensification therapy on September 6, 1995, she again presented with a red colored tumor in the left external auditory canal. Biopsy showed inflammatory granulation tissue with atypical myeloid cell and PML-RAR $\alpha$ mRNA was positive by the RT-PCR method; these findings were compatible with relapse. With BHAC $170 \mathrm{mg} / \mathrm{m}^{2}$ for 5 days, DNR $30 \mathrm{mg} / \mathrm{m}^{2}$ on days 1 and 4 intravenously and 6 -MP $70 \mathrm{mg} / \mathrm{m}^{2}$ for 7 days orally, the tumor was reduced in size, but it increased in size again. Bone marrow at that time had no morphologically abnormal cells, but was positive for PML-RAR $\alpha$ mRNA. She was treated with BHAC $170 \mathrm{mg} / \mathrm{m}^{2}$ for 5 days, etoposide $80 \mathrm{mg} /$ $\mathrm{m}^{2}$ on days 1,3 and 5 , and vindesine intravenous $2 \mathrm{mg} / \mathrm{m}^{2}$ on days 1 and 8 , followed by 20 Gy of local radiation therapy for 10 days, starting on November 28, 1995. Then, she was treated with idarubicin $12 \mathrm{mg} / \mathrm{m}^{2}$ for 3 days and BHAC $170 \mathrm{mg} / \mathrm{m}^{2}$ for 5 days intravenously, and the second complete remission was achieved. In April 1996, she again presented with an external auditory canal tumor and $10 \%$ of APL cell in her bone marrow. She achieved the third complete remission with $30 \mathrm{~Gy}$ of local radiation therapy and ATRA $45 \mathrm{mg} / \mathrm{m}^{2}$ orally daily. Then, she received three courses of chemotherapy with continuous AraC $100 \mathrm{mg} / \mathrm{m}^{2}$ for 5 days and idarubicin $10 \mathrm{mg} / \mathrm{m}^{2}$ for 3 days intravenously. She has been in complete remission for five months.

\section{Discussion}

ATRA induces remission by differentiation of APL cells without hemorrhagic complications; this is the primary cause of the early deaths. On the other hand, hyperleukocytosis and "retinoic acid syndrome" are well known, and are often fatal adverse effects associated with ATRA therapy. Dermatitis, headache, gastrointestinal symptoms, bone pain, liver dysfunction and hypertriglycelidemia are other less serious adverse events. However, short since ATRA became clinically introduced rather recently, there may be some unexpected problems associated with this agent.

Extramedullary disease has been rare in APL. Byrd et al (2) reviewed the extramedullary lesions in acute non-lymphocytic leukemia reported since 1965, and cited no APL case among 154 well documented cases. We have also reviewed other literature and found 16 cases of extramedullary disease of APL from 1965 to 1995 (3-14), and most of them were extramedullary lesions at relapse (3-12). Several investigators, however, recently described that ATRA may increase the incidence of extramedullary relapse. Indeed, 5 of 12 cases reported since 1994 were treated with ATRA $(15,16)$.

We reported here a patient treated with ATRA, who relapsed in the external auditory canal. To our knowledge, this is the first case not only as an isolated initial site of APL relapse in the external auditory canal during complete hematological remission, but also as an extramedullary relapse which was molecularly confirmed. Weiss and Warrell (15) reported a case of APL relapse in the external auditory canal, but it was associated with bone marrow relapse. Skin involvement at relapse is extremely rare in APL, especially when treated with intensive chemotherapy. Indeed, our review uncovered 8 reported cases, and 5 of them were treated with ATRA. In the past, in two studies in the Japan Adult Leukemia Study Group, there was no leukemia cutis as an initial site of relapse in 578 patients with AML including 109 patients with $\operatorname{APL}(17,18)$. Since retinoic acid reportedly upgrades the transcription of some leukocyte adhesion molecule genes (19), leukemic cells can promote endothe- 


\section{ToBITA et al}

lial adhesion and tissue migration. Giralt et al (16) hypothesized that with an increase in expression of adhesion molecules, ATRA treatment might be associated with an increase of extramedullary relapse. Careful observation for extramedullary relapses, especially leukemia cutis, will be necessary in patients with APL who were treated with ATRA.

\section{References}

1) Kanamaru A, Takemoto Y, Tanimoto M, et al. and Japan Adult Leukemia Study Group. All-trans retinoic acid for the treatment of newly diagnosed acute promyelocytic leukemia. Japan Adult Leukemia Study Group. Blood 85: 1202, 1995.

2) Byrd JC, Edenfield WJ, Shields DJ, Dawson NA. Extramedullary myeloid cell tumors in acute nonlymphocytic leukemia: A clinical review. $\mathrm{J}$ Clin Oncol 13: 1800, 1995.

3) Nihei K, Terashima K, Nito T, et al. An electron microscopic study of acute promyelocytic leukemia with chloroma. Acta Pathol Jpn 34: 159, 1984.

4) Longacre TA, Smoller BR. Leukemia cutis. Analysis of 50 biopsy-proven cases with an emphasis on occurrence in myelodisplastic syndromes. Am J Clin Pathol 100: 276, 1993.

5) Bernengo MG, Leigheb G, Zina G. A case of acute promyelocytic leukemia with bullous, hemorrhagic and necrotic skin lesions. Dermatologica 151: 184, 1975.

6) Brown DM, Kimura AE, Ossoinig KC, Weiner GJ. Acute promyelocytic infiltration of the optic nerve treated by oral trans-retinoic acid. Ophthalmology 99: 1463, 1992.

7) Baer MR, Barcos M, Farrell H, Raza A, Preisler HD. Acute myelogenous leukemia with leukemia cutis. Eighteen cases seen between 1969 and 1986. Cancer 63: 2192, 1989.

8) Haznedaroglu IC, Ustundag Y, Benekli M, Savas MC, Safari M, Dundar $\mathrm{SV}$. Isolated gingival relapse during complete hematological remission in acute promyelocytic leukemia. Acta Haematol 93: 54, 1995.

9) Deguchi A, Ohta C, Tanigawa M, et al. A case of acute promyelocytic leukemia with extradural tumor during hematological remission. Rinsho
Ketsueki (Jpn J Clin Hematol) 28: 886, 1987 (Abstract in English).

10) Matsumoto K, Taya T, Kawada K, Aoki M. A case of acute promyelocytic leukemia with skin nodules and mammary tumors during hematologic remission. Rinsho Ketsueki (Jpn J Clin Hematol) 19: 1211, 1978 (Abstract in English).

11) Ohsaka A, Saito M, Yoshida M, et al. A case of acute promyelocytic leukemia who developed disseminated necrotizing leukoencephalopathy following the therapy of meningeal leukemia. Rinsho Ketsueki (Jpn JClin Hematol) 24: 1386, 1983 (Abstract in English).

12) Sawatari $T$, Kawano F, Akahoshi $Y$, Asou N, et al. Relapse with gingival tumor during hematological remission in acute promyelocytic leukemia. Rinsho Ketsueki (Jpn J Clin Hematol) 30: 2020, 1989 (Abstract in English).

13) Ajarim DS, Santhosh-Kumar CR, Higgy KE, el Saghir NS, Alomen AK, Shipkey FD. Granulocytic sarcoma of the thymus in acute promyelocytic leukaemia. Clin Lab Haematol 12: 97, 1990.

14) Zuiable A, Aboud H, Nandi A, Powles R, Treleaven J. Extramedullary disease initially without bone marrow involvement in acute promyelocytic leukaemia. J Clin Lab Hematol 11: 288, 1989 (letter).

15) Weiss MA, Warrell RP Jr. Two cases of extramedullary acute promyelocytic leukemia. Cytogenetics, molecular biology, and phenotypic and clinical studies. Cancer 74: 1882, 1994.

16) Giralt $S, O$ 'Brien $S$, Weeks E, Luna M, Kantarjian H. Leukemia cutis in acute promyelocytic leukemia: Report of three cases after treatment with all-trans retinoic acid. Leukemia and Lymphoma 14: 453, 1994.

17) Ohno R, Kobayashi $T$, Tanimoto M, et al. Randomized study of individualized induction therapy with or without vincristine, and of maintenanceintensification therapy between 4 or 12 courses in adult acute myeloid leukemia. AML-87 Study of the Japan Adult Leukemia Study Group. Cancer 71: 3888, 1993.

18) Kobayashi T, Miyawaki S, Tanimoto M, et al. and Japan Adult Leukemia Study Group. Randomized trials between behenoyl cytarabine and cytarabine in combination induction and consolidation therapy, and with or without ubenimex after maintenance/intensification therapy in adult acute myeloid leukemia. J Clin Oncol 14: 204, 1996.

19) Hickstein DD, Hickey MJ, Collins SJ. Transcriptional regulation of the leukocyte adherence protein beta-subunit during human myeloid cell differentiation. J Biol Chem 263: 13863, 1988. 